\title{
On Negative Transfer of the Deep-structure Culture in Sino-American Communication
}

\author{
Xiaohong Wei \\ School of Literature and Law, Sichuan Agricultural University, Ya'an, Sichuan Province, China \\ Email: ongwx126@yahoo.com.cn
}

\begin{abstract}
Different nations in the world have their own cultures, and these cultures are characterized by both universality and particularity. The former provides a foundation and guarantee for intercultural communication, while the latter often leads to negative cultural transfer in communication if the speakers are unconscious of cultural differences. This paper makes a study on negative deep-structure cultural transfer in Sino-American communication, focusing on such aspects as values, thought patterns, religious beliefs and ethics. It holds that failure in intercultural communication will occur if inadequate attention is paid to cultural differences in the process of language and culture learning.
\end{abstract}

Index Terms - negative cultural transfer, Chinese and Americans, deep-structure culture

\section{BRIEF LITERATURE REVIEW OF CULTURAL TRANSFER}

Negative cultural transfer occurs in all processes of intercultural communication and foreign language learning and is of great significance in both fields. Negative cultural transfer refers to the cultural interference caused by cultural differences, which shows that people subconsciously use their cultural norms and values not only to guide their behaviors and thoughts but also to judge others' behaviors and thoughts (Dai \& Zhang, 2000). Negative cultural transfer often results in communicative difficulties, misunderstandings and even hatred.

The study of negative cultural transfer started in the field of linguistics in the 1950s. Sapir, Whorf and other linguists conducted many studies of the relationships between culture and language. They held that culture and language are inextricably interwoven, and that sociocultural values and beliefs frame the way people think and speak. Robert Lado (1957), in his book, Linguistics across Cultures, pointed out that native cultural transfer was one of the main barriers to second language learning. Later, many researchers became involved in the study of negative cultural transfer in such aspects as language forms represented by cultural linguistics (which means Guo Qing Yu Yan Xue in Chinese) of the former Soviet Union, communicative events and speech acts represented by the ethnographic study of communication of Gumperz and Hymes (1972) and the theory of speech acts of Austin (1962) and Searle (1969). Following them, Damen (1987), Kramsch (1993) and other scholars examined the importance of understanding the sociocultural values of the target language for those engaged in both second language learning and intercultural communication. They found that mastery of second language patterns alone does not ensure effective communication in the target language, and cultural education is absolutely essential for both second language acquisition and effective intercultural communication. Later, employing speech act theory, other researchers such as Beebe (1988) and Wolfson (1989) further examined how second language learners typically attempt to use speech patterns from their native language to accomplish speech acts in the second language. Beebe (1988) called this type of practice "sociocultural transfer," which, however, only refers to negative transfer of surface-structure culture because this type of transfer can be easily observed.

In recent years, attention has been paid to the study of negative cultural transfer of deep-structure culture, that is, the transfer of deeper sociocultural values and beliefs that cause the surface changes in both what people say and how people say. By examining instances of serious communication breakdowns between the native speakers and Chinese English speakers who have been in America for at least two years, Liu Dilin has revealed that negative transfer of deep-structure culture exists and seriously affects second language speakers' communication. He further states that learning second language cultural values and rules may not ensure acquisition and that acquisition of cultural competence requires immersion in a society of target language speakers (1995, p.262). Dai Weidong and Zhang Honglin (2000) also hold that negative transfer of deep-structure culture is not easily discovered because social culture and value systems exist at the psychological layer. However, it is just these cultural values that determine people's thoughts and behaviors and result in misunderstanding and ineffective communication.

The present paper aims to make a study on the negative transfer of the deep-structure culture occurring in Sino-American communication, that is, negative cultural transfer in values, thought patterns, religious beliefs and ethics. Since America is a country composed of many races, there exist cultural differences from race to race, whose ways of dealing with events are also divergent. However, it is impossible for the author to deal with all races in the present paper. Only Americans in the dominant culture, that is, White Anglo-Saxon Protestants (WASPs), are focused on in this paper.

\section{General View on Negative Cultural Transfer}


The notion of cultural transfer derives from the notion of transfer in second language acquisition. Behavioral psychologists define the term "transfer" as the automatic, uncontrolled and subconscious carryover of previous performance or knowledge to subsequent learning in an attempt to produce new responses. Many other scholars have given different definitions to this term. Among them, the most widely cited definition is the one proposed by Odlin, "transfer is the influence resulting from similarities and dissimilarities between the target language and any other language that has been previously (and perhaps imperfectly) acquired" (1989, p.27). According to this definition, cultural transfer refers to the cultural influence resulting from similarities and dissimilarities between the target culture and any other culture that has been previously acquired. Cultural transfer can be positive or negative. When one's native cultural norms are similar to the ones of the target culture, positive transfer occurs, whereas when those norms are different, negative transfer occurs. Because negative cultural transfer often results in communicative difficulties, misunderstanding and even hatred, many scholars have paid much attention to it.

To further explain negative cultural transfer, it is necessary to discuss culture first. Culture is a complicated social phenomenon, which includes everything in society and plays an important role all the time. Culture is the life patterns of a group including everything people have acquired since birth, such as language, speech forms and contents, beliefs, material and spiritual foundations that people live on. Liang Shuming, a famous Chinese philosopher and thinker, discusses three layers of culture in his book Culture and Philosophy in the East and West (1994). The first is the material life at the superficial layer, including all material things essential for human survival; the second is the social life at the intermediate layer, such as life style, social organization, political and economic relations; the third is the spiritual life at the deep layer, such as religion, philosophy, value systems, science and art (1994, p.10). The above three layers can also be termed as the physical culture at the superficial layer, the conventional culture at the intermediate layer and the psychological culture at the deep layer (Hu \& Gao, 1997, p.2-3). The physical culture and the conventional culture are tangible: people can recognize them without effort. The psychological culture is less tangible and more abstract, for it hides in the spiritual world of people. However, the psychological culture is seen as a constant influence that continues to guide people's specific behaviors, and it is more stable than the other two. In the light of the layers of culture, therefore, negative cultural transfer can be divided into two categories: the negative transfer of surface-structure culture at the physical and conventional layers of culture, and the negative transfer of deep-structure culture at the psychological layer of culture (Dai \& Zhang, 2000). However, it is worth noting that the distinction between the two categories of negative cultural transfer is not absolute. In some cases, a misunderstanding or a communicative breakdown can be understood as the result of the negative transfer of surface-structure culture, whereas it is the result of the negative transfer of deep-structure culture in some other cases.

The reasons why negative cultural transfer is one of the greatest obstacles to successful intercultural communication mainly lie in two aspects: (1) culture is deep-rooted; (2) culture is characterized by ethnocentrism. Culture is deep-rooted because most of culture is in the taken-for-granted realm and below the conscious level. Usually, the content of culture is consciously or unconsciously learned and transmitted from generation to generation. From birth, people are deeply influenced by their native culture. How they think and behave is guided by their native culture. With the development of economy and society, great changes may occur in such surface-structure cultural aspects as dress, food, transportation, housing, living habits and laws, etc., through innovation, diffusion and acculturation, but the deep structure of a culture such as values, ethics and morals, religious beliefs and ethics often resists major alterations. For example, in America, studies conducted on American values show that most of the central values of the 1990s are similar to the values of the last 200 years (Samovar, Porter \& Stefani, 2000, p.46). In addition, each culture is characterized by ethnocentrism - "the technical name for the view of things in which one's own group is the center of everything and all others are scaled and rated with reference to it"(Summer, 1940, p.13) - that has both positive and negative influence on a culture. For one thing, ethnocentrism is often a source of cultural and personal identity and has great impact on a culture's self-image; for another, it is "destructive when it is used to shut others out, provide the bases for derogatory evaluations, and rebuff change" (Damen, 1987, p.214). The feelings that we are right and they are wrong pervade every aspect of a culture's existence. Examples range from the insignificant ("Earrings should be placed on the ears, not on the nose") to the significant ("We need to build up our defenses to protect ourselves from those religious fanatics").

Nowadays, the tendency toward globalization is becoming stronger. For rapid and sustainable development, every country is trying to enhance its communication with other countries in the world. Since culture often varies significantly from country to country, it is inevitable to see some serious communicative failures, and these failures often originate from negative cultural transfer. Over the past five decades, linguistics, sociolinguistics, cultural linguistics, pragmatics and applied linguistics have all showed great interest in the study of cultural transfer. However, most of their studies are confined within the scope of surface-structure cultural transfer. Little attention has been paid to the negative deep-structure cultural transfer, because it is difficult to identify these items. However, such kind of negative cultural transfer often leads to serious problems in intercultural communication.

\section{NeGATIVE TRANSFER OF THE DEEP-STRUCTURE CULTURE}

In intercultural communication, people often take what they believe for granted because they have grown up in the culture and think their way is the best. In this case, they tend to transfer their own cultural values and beliefs to the 
situation of intercultural communication as guidelines for their behaviors, so that misunderstandings or ineffective communication arise. Generally speaking, negative transfer of deep-structure culture arises in such aspects as cultural values, thought patterns, religious beliefs and ethics.

\section{A. Negative Transfer in Cultural Values}

According to Rokeach, values are "a learned organization of rules for making choices and for resolving conflicts" (1973, p.161). These rules and guideposts are normative and teach us what is useful, right or wrong, what to strive for, how to live our life, and even what to die for. As Albert says, a value system "represents what is expected or hoped, required or forbidden. It is not a report of actual conduct but the system of criteria by which conduct is judged and sanctions applied"(1968, p.32). Every culture has its special values that tend to permeate it, which are derived from the larger philosophical issues that are part of culture's milieu. Cultural values are transmitted by a variety of sources and therefore tend to be broad-sensed, enduring, and relatively stable. The relationship between cultural values and communicative behaviors can be compared to the relationship between guiding principles and their concrete contents. In other words, people's perceptions and communicative behaviors are both guided by their cultural values. Therefore, due to the great differences in their cultural values, cultural transfer is very likely to occur in Sino-American communication.

1. Collectivism VS Individualism

China is a country deeply marked by collectivism which means greater emphasis on "(a) the views, needs and goals of the in-group (relatives, clans, organizations) rather than oneself; (b) social norms and duty defined by the in-group rather than behavior to get pleasure; (c) beliefs shared with the in-group rather than beliefs that distinguish self from in-group; (d) great readiness to cooperate with in-group members" (Triandis, 1990, p.52). A famous saying that best shows the Chinese collective thought from Confucius is "if one wants to establish himself, he should help others to establish themselves at first." In the $17^{\text {th }}$ century, English philosopher John Locke defined individualism as the doctrine that each individual is unique, special, completely different from other individuals, and the "basic unit of nature" (Stewart \& Bennett 1991, p.133). From this, we can see how important the interests of the individual are in Western culture, where all values, rights, and duties are considered to originate in individuals. Americans are obviously marked by individualism as well. The "Westward Movement" further enhanced their individual sense, because during that period people had to depend on themselves for living in newly settled western regions. Many English proverbs that demonstrate individualism are embraced by Americans, for instance, "every man is the architect of his own fortune", or "pull yourself up by your own boot straps".

In Sino-American communication, such different value orientations may lead to negative cultural transfer, especially in people's views about privacy, friendship, and relatives. In Chinese culture, such ideas as "respecting the old and loving the young", "practicing benevolence and being a good neighbor", "being always helpful to others" have been handed down from generation to generation. So in daily communication, people often show their great concern for friends or even strangers by means of such questions as, "Where are you from?", "How old are you?", "Are you married?", "How much do you earn each year?" or saying "walk/drive slowly!", "It's cold. Wear more clothes" while seeing a visitor out. In American culture, people worship the right of privacy and such topics as age, income, family, marriage, political attitude, religious belief and other things concerning individuals are generally taboos in casual conversation. As for friendship, in Chinese culture, such proverbs as "At home you count on your parents, outside on your friends" and "All men are brothers within the world" tell people how significant the friendship is and persuade people to maintain their friendships all their lives. When confronted with American "transient friendship", Chinese people are often angry and think Americans are insincere. In fact, it is social mobility and the desires for change that make Americans devalue long-term interpersonal relationships. In their opinion, self value and self-awareness are more important. In terms of relatives, family counts for much in Chinese culture, which has a complicated system of kinship terms that shows their emphasis on family, collective harmony and respect for elders. For example, they have specific terms for addressing each different relative on mother's side and on father's side. In order to establish harmonious relationship, Chinese people are even used to addressing strangers as "Granny/Grandpa Li", "Brother/Sister Wang" or "Uncle/Aunt Ma", which often shocks Americans whose kinship terms are generally vague and whose members take less responsibility for their parents or relatives.

\section{Past VS Future Orientation}

Past-oriented cultures believe strongly in the significance of prior events. History, established religions, and tradition are extremely important to these cultures, so there is a strong belief that the past should be the guide for making decisions and determine truth. China is typical of this orientation, with which Chinese often take the past as a guide for their actions in the present and more likely to worship their forefathers, and respect the elderly as well as those in authority .The proverbs "consider the past and you will know the present" and "Once a teacher, a parent forever" are apt examples. Americans, on the contrary, emphasize the future and expect it to be grander and nicer than the present. What is coming next holds the greatest attraction for most Americans because whatever they are doing is not quite as good as what they could be doing. Thus, they seldom conform to conventions and worship their ancestors and authority much less. They prefer to project themselves into the future. They set goals, target dates for meeting them, and outline specific steps for achieving goals. For them, the future is not something to dream about but something made real through concrete actions and thinking. In intercultural communication, inadequate knowledge of the great difference 
between the two value orientations may lead to misunderstanding. For instance, according to the Confucian norm, it is essential that a son observe mourning for three years to show his grief and piety when a parent dies. Otherwise, the son will be deemed not filial. Today, although this custom has been formally abandoned, its influence is still felt, and other customs are observed by people to show their filial obedience, especially in some rural areas of China. For example, holding a grand lamenting ceremony in the first three years and the tenth year after a parent dies is still practiced in some places. However, for Americans, this seems a little strange and somewhat extravagant: it is not necessary to hold such a grand ceremony at all since the parent has passed away. They can not properly understand the past preference of Chinese people, coming as they do from a position of their future preference. Americans tend to use their own future orientation to judge or treat the specific behavior of Chinese.

Additionally, a distinction exists in how to make use of time between Chinese and American cultures. In his Beyond Culture, Hall defined two kinds of time: Monochromic (M-time) and Polychronic (P-time), which represent two variant solutions to the use of time as organizing frames for activities (1976, p.17). Americans are typical of M-time. As Hall explains, "People of the western world, particularly Americans, tend to think of time as something fixed in nature, something around us and from which we cannot escape; an ever-present part of the environment, just like the air we breathe"(1959, p.19). Such proverbs as follows may reflect the time-valued perceptions of Americans: "Time and tide wait for no man."; "Time lost cannot be won again"; "Take time by the forelock". However, P-time systems are characterized by several things happening at one time. People from P-time, such as Chinese, stress the involvement of people and completion of transactions rather than adherence to present schedules. Chinese people place more emphasis on good social relationships and regard time relatively freely. Due to such differences, negative cultural transfer inevitably often occurs. This can be demonstrated in two cultures' attitudes towards "free chatting". It is sometimes seen that two or more Chinese people can spend several hours or even longer just chatting without any aim, especially in the countryside of China. Americans may be amazed at such a phenomenon and regard it as a time-wasting habit. Some may even think that Chinese people are so lazy that they are not willing to do what they should do. Thus a temporal perception transfer occurs, followed by misunderstandings. Nevertheless, they might not hold this prejudice if they understood the nature of Chinese collectivism. As mentioned above, the concept of group plays an important part in the thoughts and behaviors of the Chinese people. Therefore, in China, "treat your neighbors and relatives well" is a prevailing idea. People prefer to visit their friends or relatives or neighbors just to enhance their relationships, and they think that the more time they spend with them, the deeper their emotions are, especially in the countryside where peasants live and have more spare time. Additionally, Chinese people think that the deeper their relations are, the more easily matters are solved. "Guan Xi"(relation), as the product of collectivism, has been rooted in the Chinese people's life. Likewise, from the standpoint of collectivism, Chinese people feel uncomfortable with the haste of Americans. They complain that Americans usually show indifference to the people around them and devote their time and energy only to their own business. For Americans, however, time is an important precondition for achieving success and should not be wasted in trivial chitchat.

\section{B. Negative Transfer in Thought Patterns}

Under the influence of respective traditional worldviews and value orientations, Chinese thought patterns are characterized by synthesis, vagueness and retrospection; whereas Americans' thought patterns are characterized by analysis, precision and anticipation (Lian, 2002). Influenced by their specific thought patterns, Chinese people are used to talking or writing in a roundabout way and keeping off the point and often putting the most important or critical points at the end or even just to give a hint. Such a circular way of talking or writing is regarded as politeness in Chinese culture and it can save enough "face" for both sides. Americans, however, like coming straight to the point in conversation or writing. The topic is often mentioned at first so as to attract hearers' or readers' attention. In Sino-American communication, the transfer of thought patterns often arises at the level of discourse whose realm of study has been extended to include literary discourse and whole fields of culture and symbolic systems, among which face-to-face conversation within speech acts is paid more attention to. The following hypothetical conversation may demonstrate the striking difference in discourse pattern influenced by different thought patterns. "Mr. Wong and Mr. Richardson have a conversation. Mr. Richardson has enjoyed this conversation and when they are ready to part he says to Mr. Wong that they really should get together to have lunch sometime. Mr. Wong says that he would enjoy that. After a few weeks, Mr. Wong begins to feel that Mr. Richardson has been rather insincere because he has not followed up his invitation to lunch with a specific time and place" (Scollon, 2000, p.5).

The difference in discourse pattern expected by Asian speakers of English (such as Chinese) and by western speakers of English (such as Americans) is the source of the problem between Mr. Wong and Mr. Richardson. As is mentioned above, Americans often put the important points at the beginning of a conversation, while Chinese people are used to displacing important points until nearer the end of a conversation, which has led Mr. Wong to think that this mention of having lunch is of some importance to Mr. Richardson. Whether it is important to him or not, Mr. Wong believes that Mr. Richardson is seriously making an invitation to lunch. Mr. Richardson, however, has made such invitation at the end of his conversation because it is of little major significance. For him it does not signify any more than that he has enjoyed his conversation with Mr. Wong. It is not a specific invitation, but just a conversational way of parting with good feelings toward the other. It is this difference in discourse pattern that results in misunderstanding between two participants. 
Besides, in American culture, "straightforwardness" is regarded as a polite manner in communication, while in Chinese, indirectness is more appreciated, especially when some requests are put forward. Such a difference is sure to cause conflicts. For instance,

Mr. Jones: It looks like we're going to have to keep the production line running on Saturday.

Mr. Wu: I see.

Mr. Jones: Can you come in on Saturday?

Mr. Wu: Yes. I think so.

Mr. Jones: That'll be a great help.

Mr. Wu: Yes. Saturday's a special day, did you know?

Mr. Jones: How do you mean?

Mr. Wu: It's my son's birthday.

Mr. Jones: How nice. I hope you all enjoy it very much.

Mr. Wu: Thank you. I appreciate your understanding (Storti, 1994, p.52).

The conversation taking place between an American boss and his Chinese employee indicates that Mr. Wu is good at English but experienced a painful failure in intercultural communication due to the negative transfer of thought patterns. From the very beginning, he wanted to tell the boss that he didn't want to work an extra shift on Saturday. In Chinese culture, however, direct refusal to the boss's requirement is impolite, so he chose to refuse implicitly by saying "I see." Unfortunately, the boss didn't understand him and further forced him to land in a desperate predicament by asking a question which could be answered only by "Yes" or "No". In order to save the boss's face, he had to answer "Yes, I think so". The answer in Chinese context just meant "I hear what you say, but I don't want to come". If he was willing to come, he would say "Sure" or "Of course, I will". But the boss misunderstood him once more. Even after he told the boss that Saturday was his son's birthday, the boss didn't know what he really meant. Here Mr. Wu violated the principle of straightforwardness in American culture.

In intercultural communication, such induction of differences can only be used as a guide. It is obviously wrong to take it for granted that either Chinese or Americans only have one kind of thought pattern.

\section{Negative Transfer in Religious Beliefs}

Religion is a special form of human culture and mainly deals with the nature of life and death, the creation of the universe, the origin of society and groups within the society, the relationships of individuals and groups to one another, and the relation of humankind to nature. The study of religion not only offers insight into the spiritual and psychological needs of people, but also gives us clues into the social aspects of a culture. Great diversity exists between Chinese culture and American culture in that the two cultures are based on different traditional religions, which strongly differ from each other in doctrine. The traditional Chinese culture is based on Taoism, Confucianism, and Buddhism, among which Buddhism plays a leading role. American culture is based on many more coexisting religions, especially on the combination of ancient Greek culture with Christian culture. It is estimated that 86 percent of the U. S. population is Christian (Crystal, 1994, p.343). Although some of the specific precepts, rituals, and names applied to the term Christianity may vary (Protestants, Baptist, Methodist, Lutheran, Roman Catholic etc.), they have a multitude of important characteristics in common. Christianity permeates every corner of Americans' life, and this influences their perceptions and guides their behaviors.

The Chinese religions advocates "Oneness between Man and Nature" and stress harmoniousness, under the influence of which people are in pursuit of the unity with the nature in all aspects of life. While doing things, people emphasize, "Man proposes, Heaven disposes" and strive for timeliness, topographical advantages and the support of people. In daily life, many people believe in fate. The American religions, however, hold "Dividedness between Man and Nature" and emphasize oppositeness. Americans' self-consciousness of original sin compels them to conquer nature unyieldingly and improve themselves continuously so as to reflect divine power and then reach the combination of God with Man. In their opinion, Man is also a creator. Man and Nature are divided and opposite, but man is in a position to dominate and remake nature. In life, if one cannot gain what he wants or the status he desires, it is not, Americans believe, caused by fate, but by laziness or lack of struggle. Those who are obedient to fate are cast aside.

Under the influence of different religions, for one thing, people have different value orientations. For example, Chinese people pursue collective interests, individual sacrifice, steadiness, modesty, knowing one's place, and "Happy is he who is content", but Americans emphasize individual interests and rights including self-improvement and material success. In intercultural communication, proverbs related to religions will be completely confusing if the cultural context is not made explicit. For instance, in Chinese culture, there are such proverbs needing additional explanation as "The runaway monk cannot run away with the temple" (implying "a fugitive must belong to some place that can provide clues") and "Go on tolling the bell as long as one is a monk" (implying "take a passive attitude towards one's work"). In America, there are also such proverbs as "Love is blind" ("the blind god" is another name of the god of Love: Cupid and Erose); "God help those who help themselves" and "We must not lie down, and cry, God help us" (both emphasizing self-improvement).

Furthermore, the philosophies of life advocated by religions can even be opposite in different cultures. For example, in China, Confucianism advocates "the doctrine of the mean", Taoism holds "doing nothing that goes against nature and being contented with one's lot" and Buddhism teaches people "to be disillusioned with the mortal world and be a devout 
believer in retribution for sin". Under the influence of these doctrines, the philosophies of life typical of the Chinese culture came into being: seeking harmony and maintaining equilibrium, being worldly wise and playing it safe, which may be regarded as "passive" or "inactive" by Americans. Such precepts as "you're acting against your own interests" and "A man's life, wealth and rank are governed by life" are popular among Chinese common people. In contrast, Americans are more practical and more active in pursuit of what they want. Popular are such proverbs as "A bird in the hand is worth two in the bush" and "All is fair in love and war". In Americans' eyes, they can try every means to reach their goals without consideration of other people's interests because every one is entitled to fair competition. This, however, may be thought of as selfishness by Chinese people.

\section{Negative Transfer in Ethics}

Ethics broadly refers to judgments that focus on "degrees of rightness and wrongness, virtue and vice, and obligation in human behavior" (Johannesen, 1996, p.1). Ethics is an elusive topic. As Griffin reminds us, "Ethics has to do with the gray areas of our lives. When the psychological culture moral decisions are black and white, knowing what we should do is easy" (1994, p.458). But in many instances, we find that there is no correct moral code for all time and all people, that each group has its specific morality related to its wants and values, and that most moral ideas are necessarily relative to a particular group of people. That is to say, most ethical standards are products of particular cultures. So it is not surprising that behaviors appropriate or inappropriate to one group may be inappropriate or appropriate to another. For example, in China, intimate touch is acceptable among people of the same sex. Such touching might be regarded as inappropriate in American and Western cultures. The difference between social ethical norms is also reflected in people's attitudes towards old people. In China, people pay more attention to the virtue of showing respect for the old, including providing for one's parents, showing filial obedience to parents, and addressing the old respectfully. As for providing for one's parents, there is a vast difference between China and America. In America, elderly people mostly depend on their pension or social welfare for their livelihood. Children do not have to support their parents. In China, nevertheless, the majority hold that grown-up children should care for their elderly parents. Article 15 of Chinese Marriage Law also stipulates that adult children have the obligation to provide for and financially assist their parents. If they don't, theoretically the parents could take their children to court. Thus, in China, those who do not support their elderly parents will be condemned morally or even punished legally. Additionally, in daily life, people often address the elderly "Old Li", "Old Grandpa", "Old Superior", in which "Old" means "experienced" or "authoritative". This custom is rarely observed by Americans because in American culture, "old" may mean "useless".

It is clear from the above discussion that culture has a strong influence on subjective reality and that there are direct links among language, culture, and communicative behavior. The way cultures view reality determines how people see the world and interact in that world. Thus, communication behavior-how people react to their perception of the world - is largely a result of their learning and cultural conditioning. In spite of assimilation of world cultures, each culture has its particularity, which is deep-rooted and is inevitably reflected in its language and people's behaviors.

\section{CONCLUSION}

Although this paper only explores negative deep-structure cultural transfers caused by cultural differences between China and America from the group viewpoint, such analysis and exploration are necessary and helpful to foreign language learners because general knowledge about other cultures is the first key to knowing a completely new culture. Without this key, we are sure to judge and understand the foreign culture from our own point of view, which is bound to cause communicative failure. On the other hand, over-generalized knowledge can also hinder our understanding and communication because individual differences exist within all cultures. For full understanding, it is necessary to break apart simple cultural stereotypes with the depth of our learning and to form a kind of sensitivity to nuances in cultural differences. Together with tolerant attitudes towards foreigners and certain communicative strategies, such deep learning helps to avoid misunderstandings and even more serious conflicts in intercultural communication.

\section{REFERENCES}

[1] Albert, E. (1968). "Value System," in The International Encyclopedia of the Social Sciences, Vol. 16. New York: Macmillan.

[2] Austin, J.L.(1962). How to Do Things with Words. Oxford: Clarendon Press.

[3] Beebe, L. M. (1988). Issues in Second Language Acquisition: Multiple Perceptives. New York: Newbury House.

[4] Crystal, D. (1994). The Cambridge Factfinder. New York: Cambridge University Press.

[5] Dai, Weidong \& Zhang, Honglin (2000). The Negative Cultural Transfer in Foreign Language Communication and Its Implication for English Teaching Reforms. Foreign Language World, 78(2), 2-8.

[6] Damen, L.(1987). Culture Learning: The Fifth Dimension in the Language Classroom. Reading, MA: Addison Wesley.

[7] Griffin, E. A. (1994). First Look at Communication Theory (2 $2^{\text {nd }}$ ed.) New York: MC Graw-Hill. ghai Far-East Press.

[8] Gumperz J.J. \& Hymes D. (1972). Directions in Sociolinguistics: The Ethnography of Communication. New York: Holt, Rinehart and Wiaston.

[9] Hall, E.T.(1959). The Silent Language. New York: Doubleday.

[10] Hall, E.T. (1976). Beyond Culture. New York: Doubleday.

[11] Hu, Wenzhong \& Gao Yihong (1997). Foreign Language Teaching and Culture. Changsha: Hunan Education Press.

[12] Johannesen, R.K.(1996). Ethics in Human Communication $\left(4^{\text {th }}\right.$ ed.) Prospect Heights, IL: Waveland Press. 
[13] Kramsch, Claire. (1993). Context and Culture in Language Teaching. Oxford: Oxford University Press.

[14] Lado, R.(1957). Linguistics across Cultures: Applied Linguistics for Language Teachers. Ann Arbor: University of Michigan Press.

[15] Liang, Shuming. (1994). Culture and Philosophy in the East and West. Shanghai: Shanghai Far-East Press.

[16] Liu, Dilin. (1995). Sociocultural Transfer and Its Effect on Second Language Speakers' Communication. International Journal of Intercultural Relations. vol.19, No. 2, 261-268.

[17] Lian, Shuneng. (2002). On Thinking Ways of Chinese and Western Cultures, Foreign Languages and Their Teaching, 155 (2), 40-46.

[18] Odlin, T. (1989). Language Transfer. Cambridge: Cambridge University Press.

[19] Rokeach, M.(1973). The Nature of Human Values. New York: Free Press.

[20] Samovar, L.A., Porter, R. E. \& Stefani, L. A. (2000). Communication between Cultures. Beijing: Foreign Language Teaching and Research Press.

[21] Scollon, R. \& Scollon S. W. (2000). Intercultural Communication: A Discourse Approach. Beijing: Foreign Language Teaching and Research Press.

[22] Searle, J. (1969). Speech Acts. An Essay in the Philosophy of Language. Cambridge: Cambridge University Press.

[23] Searle, J. (1979). Expression and Meaning: Studies in the Theory of Speech Acts. Cambridge: Cambridge University Press.

[24] Stewart, E. C. \& Bennett, M. J. (1991). American Culture Patterns: A Cross-Cultural Perspective. Yarmouth, Maine: Intercultural Press.

[25] Storti, C. (1994). Crosscultural Dialogues. Yarmouth: International Press.

[26] Summer, W.G. (1940). Folkways. Boston: Grinnand.

[27] Triandis, H. C. (1990). Cross-Cultural Studies of Individualism and Collectivism. In J. J. Berman, (ed). Cross-Cultural Perspectives. Lincoln: University of Nebraska Press.

[28] Wolfson Nessa. (1989). Perspectives: sociolinguistics and TESOL. New York: Newbury House.

Xiaohong Wei was born in Jianyang, Sichuan Province, China in 1971. She received her M. A. degree in Foreign Linguistics and Applied Linguistics from Sichuan University, China in 2004.

She is currently a professor in school of literature and law, Sichuan Agricultural University, China. Her research interests include intercultural communication as well as culture and translation. 